NBER WORKING PAPER SERIES

\title{
CONFRONTING DIVERGENT INTERESTS IN CROSS-COUNTRY REGULATORY ARRANGEMENTS
}

\author{
Edward J. Kane \\ Working Paper 11865 \\ http://www.nber.org/papers/w11865 \\ NATIONAL BUREAU OF ECONOMIC RESEARCH \\ 1050 Massachusetts Avenue \\ Cambridge, MA 02138 \\ December 2005
}

The views expressed herein are those of the author(s) and do not necessarily reflect the views of the National Bureau of Economic Research.

(C2005 by Edward J. Kane. All rights reserved. Short sections of text, not to exceed two paragraphs, may be quoted without explicit permission provided that full credit, including $(\odot$ notice, is given to the source. 
Confronting Deivergent Interests in Cross-Country Regulatory Arrangements

Edward J. Kane

NBER Working Paper No. 11865

December 2005

JEL No. G21, G28, P51

\begin{abstract}
$\underline{\text { ABSTRACT }}$
Although nation-based systems of financial regulation constitute a second-best approach to global welfare maximization, treacherous accountability problems must be acknowledged and resolved before regulatory cooperation can deal fairly and efficiently with cross-border issues. To track and control insolvency risk within and across any set of countries, officials must construct a partnership that allows regulators in every participating country to monitor and to influence counterpart regulators in partnering nations. Using efforts to harmonize the Australian and New Zealand regulatory systems as an example, this paper identifies characteristics by which regulatory systems differ and underscores particular features that make regulatory harmonization difficult to achieve.

Edward J. Kane

Department of Finance

Boston College

Chestnut Hill, MA 02458

and NBER

edward.kane@bc.edu
\end{abstract}


December 2, 2005

\section{CONFRONTING DIVERGENT INTERESTS IN CROSS-COUNTRY REGULATORY \\ ARRANGEMENTS* \\ Edward J. Kane \\ Boston College}

As financial institutions and markets more and more effectively transcend geographic borders, limitations of national systems of regulation become more consequential. Beginning with the five-page Basel Concordat of 1975, banking regulatory agencies in major countries have agreed that multinational banking organizations should be supervised in a cooperative manner by both their "home" and "host" countries. The Concordat assigns home-country supervisors responsibility for consolidated oversight of global conglomerate banking organizations, while it leaves host-country regulators responsible both for supervising the local operations of foreign and domestic banks and for sharing relevant information about local operations with home-country regulators. The Concordat's conflicting goals were to assure adequate cross-border supervision of multinational banks, while reducing the total regulatory burden generated across the jurisdictions in which the bank might operate and respecting a host country's right to set its own domestic standards for individual-bank safety, system stability, and the accumulation of market power.

Under the aegis of the Basel Committee on Banking Supervision (the Basel Committee), the Concordat spurred a search for minimum prudential standards that evolved by 1997 into a 44-page statement of Core Principles for Effective Banking Supervision. These fluid principles are gradually congealing into amplifying criteria that teams of outside experts can use to make country-by-country assessments of regulatory effectiveness (Basel Committee, 2001). In turn, these criteria are helping to shape a new and more-complicated system of risk-based capital requirements knows as "Basel II" (Basel Committee, 2003). Basel II focuses the conflict between home and host regulators on how to verify and share information across countries and how to use whatever data they share to allocate a conglomerate institution's capital and diversification benefits between local and home-country exposures to insolvency risk. As in ordinary human

* For helpful comments on earlier drafts, the author wants to thank Richard C. Aspinwall, David Mayes, numerous staff members at the Reserve Bank of New Zealand, and seminar audiences at Victoria University 
affairs, the need to mitigate or overcome bankers' and foreign regulators' incentives to hide embarrassing information is a central feature of conscientious bank supervision.

Although nation-based systems of financial regulation obviously constitute a second-best approach to global welfare maximization, treacherous accountability problems must be acknowledged and resolved before regulatory cooperation can deal fairly and efficiently with cross-border issues. To track and control insolvency risk within and across any set of countries, officials must construct a partnership that allows regulators in every participating country to monitor and to influence counterpart regulators in all partnering nations. Using efforts to partner the Australian and New Zealand regulatory systems as an example, this paper identifies characteristics by which regulatory systems differ and underscores particular features that make harmonization difficult to achieve.

\section{Trans-Tasman Regulatory Harmonization as an Illustrative Case}

Troubled banks routinely conceal unfavorable information about their performance or condition from outsiders. Bank customers and counterparties acting on their own cannot easily uncover this information. Partly to overcome this coordination problem, government chartering and supervision of banks and payments systems are near-universal phenomena. Regulatory activities may be described as efforts by a trusted Third Party that affect the shaping, pricing, and delivery of banking products in one of three ways: by rule-making (e.g., capital requirements); by monitoring and enforcement; or by detecting and resolving insolvencies (i.e., shortages in bank-contributed net worth).

To the extent that the beneficiaries and the regulated are different parties, banking regulation is "other-regarding" and "other-directing." A principal goal is to protect society from the consequences of excessive risk-taking, capital shortages, and loss concealment at individual banks. To maximize global welfare, contracts under which officials are appointed would have to make them or their agencies explicitly accountable to potential loss-bearers in all partner countries for all costs incurred in preventing, detecting and resolving bank insolvencies. 
The Basel Concordat and its later elaborations call for contact and cooperation between host and parent supervisory authorities. In the absence of harmonizing contact and cooperation, contractual arrangements focus banking regulators in each country on domestic interests. They would be expected to design and operate regulatory enterprises nationalistically, i.e., with an eye toward maximizing primarily the welfare of their own citizens.

It is important to recognize that policy coordination cannot eliminate crosscountry and within-country incentive conflicts in banking regulation. At best, it may establish a contractable partnership that supplements—without substituting for-policies of sound regulatory discipline in individual countries.

Mishan (1969) emphasizes that economic policy performance should be assessed in two dimensions. Optimal strategies produce outcomes that are simultaneously Paretoefficient and "distributionally preferred" (i.e., they help the representative citizen and avoid antiegalitarian effects on the distribution of income). ${ }^{1}$ The Mishan criterion reminds us that cross-country arrangements to detect, prevent, and resolve bank insolvencies must not result in increased loss exposures that disadvantage the citizens of any partner country.

As stewards of taxpayer resources, the Mishan criterion implies that in each country financial supervisors and regulators owe four duties to the representative citizen:

1. $\underline{\text { Vision }}$ (maintaining a capacity to recognize risk-taking and capital shortages in timely fashion);

2. Prompt corrective action (being committed to control the value of implicit and explicit government guarantees);

3. Least-cost resolution (efficiently curing insolvencies that corrective action fails to avert);

4. Truth-telling (keeping voters and taxpayers informed about the true opportunity costs of regulatory strategies).

\footnotetext{
${ }^{1}$ In the words of Andrew Jackson [quoted in Todd (2002)]: "In the full enjoyment of . . . the fruits of superior industry, economy, and virtue, every man is equally entitled to protection by law; but when the laws undertake to add to these natural and just advantages artificial distinctions to grant titles, gratuities, and exclusive privileges to make the rich richer and the potent more powerful, the humble members of society - the farmers, mechanics, and laborers-who have neither the time nor the means of securing like favors to themselves, have a right to complain of the injustice of government (1832)."
} 
Gaps in vision and reporting obligations engender incentive breakdowns. They reduce society's ability to hold regulators responsible for uncovering the truth about bank losses and acting on it. This weakness in communicating societal disapproval undermines a regulator's incentive to prevent insolvencies and to resolve them efficiently. Being able to hide lapses in performance intensifies incentive conflict. It makes it easier in tough times to pursue short-run political and career rewards that top officials can capture by not closely enforcing economic insolvency.

Sincere efforts to integrate the private banking markets of any two countries-in particular, those of Australia (A) and New Zealand (Z) — must also plan to integrate their private and governmental systems of information disclosure and banking regulation. Regulatory integration is complicated because, even if regulatory strategies and control structures $\left(\mathrm{R}_{\mathrm{A}}, \mathrm{R}_{\mathrm{Z}}\right)$ did not differ greatly between the countries, individual-country regulators are responsible to different sets of taxpayers $\left(\mathrm{T}_{\mathrm{A}}, \mathrm{T}_{\mathrm{Z}}\right)$ and social norms and applicable legislation makes private and governmental regulatory officials accountable to their citizens in disparate contractual ways $\left(\mathrm{C}_{\mathrm{A}}, \mathrm{C}_{\mathrm{Z}}\right)$. To maximize the joint welfare of citizens of both countries, it is not enough to blend the countries' strategies and control structures. To harmonize regulatory incentives, regulatory performance measures and reporting responsibilities must be refocused as well.

A country's regulatory system co-evolves with popular perceptions of what regulatory problems cry out to be solved. When citizens believe their country's incentive-control system is working adequately, it is hard to build a coalition strong enough to win marked changes in regulatory strategies and tactics. This is why substantial regulatory reforms usually occur only in the wake of large-scale crises.

In noncrisis times, lobbying activity can seldom achieve more than a marginal adjustment either in the objectives that officials pursue or in the tradeoffs officials make within the limits of their regulatory culture. How particular policy strategies actually work in practice is co-determined by the rules officials adopt and by regulatees' ability to find and exploit circumventive loopholes in the enforcement of these rules. One reason that the issue of cross-border regulatory cooperation is on the table around the world is that exploiting loopholes often entails moving activities that one country might tax more heavily or regulate more effectively into the jurisdiction of another. 
With large Australian-owned institutions holding over 85 percent of the New Zealand banking market, harmonization is a hot-button issue in both countries. Although the two countries agreed in early 2005 to establish a joint Trans-Tasman Council on Banking Supervision, the initial hopes and fears of officials in $\mathrm{A}$ and $\mathrm{Z}$ seemed to differ sharply. Australian Treasurer Peter Costello portrayed harmonization as a process of negotiation in which a single system of "seamless" regulation would be the most desirable endpoint, while New Zealand Finance Minister Michael Cullen took care to label a single regulatory system as merely a "possible endpoint" (Joint Press Conference, Feb. 18, 2005).

New Zealand citizens could draw little comfort from a follow-up interview that Treasurer Costello offered in the February $19^{\text {th }}$ Weekend Herald. He described his vision for the two countries as one in which "goods and services will move as seamlessly across the Tasman in much the same way they now move seamlessly across the Victorian and New South Wales border." To the extent that states rights in Australia fall short of absolute sovereignty, this vision comes perilously close to expressing an intention to reduce New Zealand financially to Australia's seventh state or third territory.

The over-riding task of financial regulation is to resolve diverse incentive conflicts in financial transactions at minimum net cost to society. Treasurer Costello's position assumes that dual supervision generates only "duplication and unnecessary cost." An alternative view is that, especially where bank risk exposures and capital positions are hard to detect and easy to shuffle across jurisdictions, two heads are likely to prove better than one. This view is buttressed by the undeniable value to New Zealand citizens of ensuring that officials in any post-harmonization regulatory enterprise remain democratically accountable for identifying and protecting Kiwi interests and especially for preventing and managing the dangers and costs of future banking crises. It is not for nothing that the New Testament warns of the impossibility of faithfully serving two masters.

Any system of government generates different costs and benefits for differently situated citizens and corporations. It is natural for large Australian banks to ask their government to help them reduce their total taxes and regulatory compliance costs. It is just as natural for New Zealand citizens to worry about how well their interests would be 
represented in an evolving global banking system if their concerns had to be filtered through the economic interests of Australian banks and the political interests of Australian regulators.

The Trans-Tasman Council's central contracting problem is to recognize and ameliorate conflicts between societal and private interests that exist in Tasman-area markets for banking services. Woolford and Orr (2005, p. 46) define the Council's main goal as promoting "maximum coordination, cooperation, and harmonisation of transTasman bank regulation where sensible." To me, this means integrating one country's regulatory system with that of the other country without eroding the advantages and democratic responsibilities of either. To accomplish this task, conferees must develop transparent measures of bank and regulatory performance and incorporate these measures into a self-enforcing contractual structure that empowers citizens of both countries to hold officials accountable for the tradeoffs they make between joint and national interests (Schüler, 2003).

\section{Primacy of Controlling Incentive Conflict}

In banking, depositors and other outside stakeholders may be exposed to loss from fraud, leverage, or earnings volatility without being adequately informed or compensated for the risks entailed. To reduce their exposure to these three types of risk shifting, a bank's counterparties deploy three remedies: (1) they require the bank to bond itself in various ways to behave honestly and fairly; (2) they negotiate a deterrent right to punish opportunistic behavior; and (3) they monitor information on the bank's ongoing performance and condition.

Bonding, policing, and monitoring are not costless. The costs vary inversely with the transparency $(\mathrm{T})$ provided by the accounting and disclosure regime under which the bank operates. The more transparent the disclosure regime, the more easily and more accurately outsiders-depositors, investors, and supervisors-can estimate the true value of a bank's assets and liabilities. But policing costs are also a function of outside stakeholders' ability to appreciate the implications of the information they receive (i.e., 
their financial expertise) and their ability to coordinate deterrent and punitive responses with others (i.e., their disciplinary power).

In the absence of credible third-party guarantees, financially sophisticated counterparties act as keynoters whose actions put strong pressure on banks known to be experiencing opportunity-cost losses to adjust their affairs promptly. The market forces keynoters unleash require troubled banks to do one or all of three things: shrink their footings, raise more capital, or pay higher interest rates on their deposits and other debt.

In monitoring, disciplining, and resolving banks, the incentives of government officials to act promptly differ from the duties and incentives of private creditors in important ways. Because official interventions are unusual and generate a great deal of publicity, officials cannot focus only on the economic costs and benefits of the intervention. Given that disadvantaged parties would be all too ready to accuse them of creating or escalating problem situations, regulators must worry about the political and career ramifications of even the most-dutiful interventions. Even small interventions can damage their professional reputations and careers if their policies distress powerful parties.

Although many commonalities of interest exist, governmental systems for setting and enforcing financial rules are infested with incentive conflict. Even within a country, major conflicts exist between and among:

1. Regulators and the firms they regulate;

2. Particular regulators and other societal watchdogs;

3. Regulators and the politicians to whom they must report;

4. Taxpayers and the politicians and regulatory personnel they put in office. How a country traditionally approaches and resolves these conflicts is in part hard-wired into its political and institutional structure. To different extents, societies impose bonds of community on individual citizens. Ideally, these bonds restrain corporate and governmental decision making in socially beneficial ways. Communal bonds generate an internally and externally enforced sense of reciprocity that inserts into individual preference functions a concern for one another's welfare that deters at least some forms of opportunistic behavior. To reinforce these implicit controls, a country also works out ways for watchdogs to fill gaps in the bonding, deterrent rights (deterrency), and 
transparency inherent in its private contracting environment. Over time, efforts to close gaps in private and government contracting generate a country-specific regulatory culture.

\section{Difficulty of Resolving Divergences in Regulatory Culture}

When private corporations merge, the goal of the transaction is to create value by enhancing the capabilities and performance of partner firms. To be successful, managers of the combined enterprise must identify synergies and mitigate conflicts of interest among various stakeholders. Especially in cross-border combinations, empirical evidence indicates that marked differences in either the corporate cultures or strategic orientations of partnering firms reduce the chance that they can be merged successfully (Weston, Siu, and Johnson, 2001, p. 639); Altunbas and Ibáñez, 2004).

This section begins by defining a regulatory analogue to the concept of corporate culture. This concept provides a systematic way to compare and contrast the specific regulatory strategies and tactics employed in Australia and New Zealand. Despite a number of fundamental similarities, important differences in culture can be identified. From an evolutionary perspective, the very persistence of these differences indicates that, within each country, idiosyncratic features manage to resolve incentive conflicts with reasonable efficiency. The Trans-Tasman council cannot hope to build a system that stitches together in compromise fashion an equal number of pieces from the different regulatory systems without losing the threads of economic logic that underlie them. If these threads are not rewoven carefully enough, the citizens of one or both partner countries will suffer substantial welfare losses.

The Concept of Regulatory Culture. A culture may be defined as customs, ideas, and attitudes that members of a group share and transmit from generation to generation by systems of subtle and unsubtle rewards and punishments. A regulatory culture is more than a system of rules and enforcement. It incorporates higher-order norms about how 
officials should comport themselves; these norms limit the ways in which uncooperative or even unscrupulous individual bankers can be monitored and disciplined. It includes a matrix of attitudes and beliefs that define what it means for a regulator to use its investigative and disciplinary authority honorably. These attitudes and beliefs set standards for the fair use of government power. Checks and balances that bound each agency's jurisdiction express a distrust of government power that often traces back to abuses observed in a distant past when the country was occupied, colonized, or run by a one-party government. Underlying every formal regulatory structure is a set of higherorder social norms that penetrate and shape the policy-making process and the political and legal environments within which intersectoral bargaining takes place. These underlying standards, taboos, and traditions are normative in two senses. They simultaneously define what behaviors are "normal" and what behaviors regulators should mimick to avoid criticism or shame.

Prudential regulation imposes on regulators a duty to stop excessive risk-taking and to find and resolve hidden individual-bank insolvencies in timely fashion. Within any country, the Regulatory Culture within which this duty is discharged is spanned by six specific components:

- Legal authority and reporting obligations

- Formulation and promulgation of specific rules

- Technology of monitoring for violations \& compliance

- Penalties for material violations

- The regulator's duties of consultation: To guarantee fairness, regulated parties have a right to participation and due process, which imposes substantial burdens of proof on the regulator

- Regulatees' rights to judicial review: Intervened parties have an access to appeals procedures that bond the fairness guarantee.

$\underline{\text { Similarities in Australian and New Zealand Regulatory Cultures. }}$

In Australia and New Zealand, the last three dimensions of regulatory culture are fundamentally the same. Both countries accept social norms that subject official decisions to intragovernmental checks and balances and require them as well to treat 
violators as innocent until formally proven guilty and to assure that punishments meted out do not exceed the social importance of the violations at issue. The presumption of innocence protects fraudsters and bumblers from prompt regulatory discipline; the other two norms make it impossible to make penalties draconian enough to eliminate riskshifting incentives completely.

By increasing the difficulty of proving a bank to be insolvent, tests of regulatory authority, fairness, and reasonableness prolong the process of detecting and resolving insolvencies. Even a deeply insolvent institution can delay and ameliorate disciplinary actions in two-ways: (1) by delaying writedowns of impaired assets, and (2) by accumulating political clout and using it to generate outside (and not always proper) interference on its behalf.

Differences in the Allocation and Implementation of Legal Authority. Despite sharing almost identical legal norms, the regulatory systems of the two countries differ importantly in each of the first three dimensions. The Reserve Bank of New Zealand (RBNZ) combines specialized prudential supervision of the NZ banking system with the tasks of conceiving and executing monetary-policy actions. Conduct-of-business regulation and supervision of financial firms in nonbank sectors is conducted by other agencies. In Australia, the relatively new Australian Prudential Regulatory Authority (APRA) follows the British model of leaving monetary policy to the central bank [The Reserve Bank of Australia (RBA)], and exercises supervisory authority in an integrated manner over insurance companies, depository institutions, and some types of securities firms.

These different structures of prudential regulation allocate responsibility for preserving financial stability in very different ways. Unlike APRA, the RBNZ at present has no formal responsibilities for supervising nonbank institutions (Mortlock, 2003). Unlike the RBNZ, APRA leaves policy decisions that affect interest-rate and exchangerate volatility to the RBA, even though monetary-policy decisions can work potentially devastating effects on an individual bank's solvency and risk profile.

Several other ways of allocating legal authority for promoting financial stability are used by other countries. For example, the U.S. central bank combines monetary- 
policy authority with supervisory responsibilities, but competes for and shares supervisory jurisdiction over banks with many other regulators. Several European countries task their central bank with supervising securities firms and banks in tandem.

The great diversity we observe in how supervisory authority is allocated supports this paper's central hypothesis that different ways of dividing supervisory and monetarypolicy responsibility have particular advantages and disadvantages, with the balance of costs and benefits varying with the character of a country's financial and political contracting environment. Common sense and Samuelson's principle of revealed preference tell us that each country's current structure is better suited to its own particular financial environment than any other country's would be.

Interaction of Differences in Monitoring Methods, Rules, and Enforcement. The goal of all systems for supervising banks is the same: to assure a safe and sound financial environment by protecting depositors and the economic health of the nation as a whole from hidden and disruptive bank risk-taking. Ideally, rules and the ways they are enforced are designed to detect losses and imprudent risk exposures and to resolve capital shortages at banks before they can become deep enough to cause widespread disruption.

As explained earlier, authorities' vision is constrained by leeway in accounting standards and by the larger disclosure regime in which their banks operate. The rules and enforcement methods by which authorities pursue financial stability must be tailored to overcome weaknesses not only in their own vision, but also in the vision of partner regulators and in the bonding, deterrency, and transparency in their private contracting environments.

Disclosure regimes place a web of formal and informal obligations on bank managers, accountants, and directors. These obligations determine what asset and liability items bank accountants must report values for, what changes in value must be reported (either on the balance sheet or in footnotes), and when and how authorities are to be informed about emerging losses.

In all countries, independent external accountants assume a responsibility for reporting accurate information to directors, creditors, stockholders, regulators, and other outsiders, even if the managers that hire them would prefer to cook the books in 
misleading ways. Similarly, bank directors have a duty to review and test audit reports for accuracy and to assure themselves and regulators that the bank is being managed well.

An effective regulatory partnership must impose sensible and enforceable regulator-to-regulator disclosure obligations all around. When top regulators receive strong evidence that crippling losses may be emerging at an individual bank, duty must also require them to dispatch a team of forensic analysts to measure the extent of these losses. When the special exam is completed, regulators are expected to share the findings with the bank's directors. At this point, directors could request a brief window of time to give them a chance to cure the bank's capital shortages. If sufficient new capital is not subscribed, the bank would be closed, offered to a new owner, or placed in statutory management. The task of statutory managers would be to decide afresh whether and when to liquidate the bank or offer it for sale.

In both Australia and New Zealand, auditors are required to report to the supervisory authority any evidence they uncover of actual or potential insolvency and to alert authorities about possible violations of prudential standards. Accountants must attest that nothing that "has come to their attention" in preparing or reviewing financial statements would cause them to believe that the bank's financial statements and supplementary disclosures do not present a "true and fair view" of the matters to which they relate. Section 96 of the Reserve Bank of New Zealand Act requires auditors to disclose directly to the RBNZ any information that is "likely to assist, or be relevant to the exercise by the bank of its powers under this part of this act" [i.e., the RBNZ's supervisory powers]. The same section obliges a bank's auditors to alert the RBNZ if they believe the bank is either "insolvent or is likely to become insolvent or is in serious financial difficulties." Section 97 requires auditors to "take reasonable steps to inform the registered bank" of their intention before expressing their concern to the RBNZ, and Section 98 protects auditors that make good-faith disclosures from civil and criminal liability or professional sanctions. The legal force of these provisions is to assure that inserting exculpatory clauses into their articles of engagement cannot relieve auditors of legal liability for not reporting evidence of a developing bank insolvency. The social force of these provisions comes from an individual's desire to enjoy the esteem of his or 
her fellow citizens and to avoid disgrace. Experience suggests that most auditors are considerably more concerned about potential lawsuits than their social standing.

The most important difference in the supervisory regimes of Australia and New Zealand is the strength of the obligations that they place on bank directors to uncover and transmit unfavorable information to top regulators (Brash, 1996). In Australia (indeed in most countries other than New Zealand), bank managers, auditors, and directors may (if they are careful about it) use loopholes in accounting rules to delay the transmission of adverse information to regulators. Table 1 lists the alternative ways that news of crippling losses may first come to light. It also lists the ways that managers, directors, and lower-level regulatory staff members may sugarcoat bad news or temporarily blockade the various paths through which bad news can reach top regulators.

For directors of registered banks, New Zealand's disclosure regime imposes selfreporting obligations that all but eliminate impunity for director-supported misrepresentation. All directors must sign quarterly statements indicating whether "after due enquiry" they believe: (1) that the General Disclosure statement [Tripe (2001) describes the content of this document] contains all information required and is neither false nor misleading, (2) that the bank has complied with various regulations (including rules on lending to connected persons), and (3) that the bank has in place and is properly applying systems that adequately monitor and control material risks, a great many of which are named explicitly. Finally, to do business in New Zealand, large Australian banks must be locally incorporated. While no explicit residential requirement yet exists, it has been understood that the chief executive should reside in New Zealand so that he or she could be prosecuted for false disclosures without extradition proceedings.

So far, directorial self-reporting has served New Zealand well. The threat of legal and reputational penalties for false attestations have surfaced relevant supervisory issues both as a result of changes occurring at individual banks and as a result of changes made in the wording of RBNZ attestation requirements. Cautious directors of particular banks have on several occasions scheduled meetings with RBNZ senior staff to inform them promptly of concerns that interfere with their signing the required statements. Similarly, when the RBNZ has encountered inconsistencies in attestations and reports, RBNZ staff have initiated the same sort of meetings. 
This special channel of verification focuses rule-making on what positions or facts should be disclosed to the RBNZ and how the accuracy of disclosures should be certified. Except for a web of specific restrictions on insurance activities and loans to connected firms and persons, the RBNZ eschews formal limits on the size of particular bank positions. It presumes that directorial disclosure obligations will identify losses and imprudent loss exposures in a more relevant and more timely manner than a rigid program of position caps and periodic inspections for breaches by government examiners could.

In contrast, position caps and confidential government inspections play starring roles in Australia's supervision of banks. Of course, the effectiveness of either regulatory regime is routinely undermined by regulation-induced innovation. Still, government supervisors are never going to know enough about the motives for financial innovation to design ratios that can serve as an effective first line of defense against risk-shifting by troubled banks. The presumption that particular portfolio positions are either prohibitively risky in themselves or signify failure-producing risk-taking ignores both the value that any risky position may have in diversifying other risks and the rich and growing menu of techniques that banks use to hedge or intensify broad categories of risktaking today. The pace of innovation in techniques of risk-taking and risk management virtually guarantees that with every passing day, balance-sheet ratios that predicted failure in the past become less and less reliable measures of a modern bank's proneness to failure. Both in rule-making and in monitoring, the continuing expansion and growing complication of structured and index derivatives keep government supervisors' riskassessment capabilities lagging behind those of the banks they regulate. However, impairments to regulatory vision and verification are less daunting in that many of them can be contracted away.

Summary. In Australia and indeed in most other countries, inspection-based supervision is a game of hide the cheese. The cheese, of course, is adverse information about a bank's true condition or periodic performance. Loopholes in the rules of the game incentivize bank directors to help managers to mislead supervisors and other outsiders. They can do this with impunity as long as the firm makes skillful and legitimate use of an 
evolving set of professionally certified accounting loopholes. Like night-club illusionists, managers and accountants may even expect ethically challenged directors to admire their proficiency in using smoke and mirrors to make losses and loss exposures invisible to the naked eye.

The distinctive feature of New Zealand's post-1996 regulatory culture is that selfreporting obligations imposed on directors simplify the supervisory burden of uncovering and proving fraud and insolvency. It makes it illegal and disreputable for individual bank directors to assist others in perpetrating an illusion. Directors are required by law to bring to the attention of the supervisor important adverse information they happen to come across. This duty is enforced by substantial criminal and civil penalties and intensified by the reputational harm that timely public exposure of formally illicit behavior inevitably brings.

Even with substantial prior notice, replacing either country's regulatory system by the other would be extremely disruptive for the country whose supervisory traditions would be pushed aside. It seems more sensible to focus on finding ways to network the two systems in a cooperative way and to explore experimentally which particular strategies and tactics can provide enough vision to control economic and financial stress within and across the partner countries.

IV. The Role of Regulatory Culture in the Insolvency Detection and Bank Failure Process

Economists define economic net worth $\left(\mathrm{N}_{\mathrm{E}}\right)$ as the full-information value of a firm's tangible and intangible assets and liabilities. In statistical terms, accounting or book-value net worth $\left(\mathrm{N}_{\mathrm{BV}}\right)$ becomes a poorer and poorer estimator of $\mathrm{N}_{\mathrm{E}}$. As the latent variable $\mathrm{N}_{\mathrm{E}}$ declines, the estimator $\mathrm{N}_{\mathrm{BV}}$ becomes increasingly more biased and inefficient.

In effect, regulatory vision falters when it is most needed. This makes accounting insolvency a dangerously unreliable threshold for winding up the affairs of a troubled bank. Opportunities to defer the accounting realization of economic losses render accounting net worth a lagging indicator of the extent of a troubled bank's capital shortage. When a financial institution's survival is threatened, adverse information 
becomes harder and harder to detect in accounting reports. The threshold at which authorities can force stockholders to either recapitalize a troubled bank or surrender their franchise must be set high enough to compensate for this predictable decline in acuity.

Historical experience shows that, with a zero $\mathrm{N}_{\mathrm{BV}}$ threshold, financial institutions' ability to conceal risky transactions and impairments in asset values from outside eyes can allow economic insolvencies to reach costly depths before authorities can address them (Honohan and Klingebiel, 2003). Weaknesses in loss detection and regulatory intervention rights can spawn a systemic crisis by enabling insolvent institutions to adopt aggressive risk-taking strategies that—by destroying profit margins—spread insolvency to competing institutions.

Crisis-Driven Reforms in New Zealand and the United States According to Honohan and Klingebiel (2003), New Zealand's banking system was in crisis between 1989 and 1992 (see also Ledingham, 1995). Several foreign-owned banks had to be recapitalized by their parents, but a number of financial firms failed, one of which was a major institution: the Development Finance Corporation (in 1989). Although DFC was not a commercial bank, it was the seventh-largest financial institution in New Zealand. As the first important financial insolvency to occur in many years, the need to resolve its affairs was a systemic event that disrupted credit flows and put the viability of a few other institutions into question. Winding up its affairs took many years and absorbed a great deal of supervisory resources.

According to Brash (2000), the country's largest bank [the Bank of New Zealand] would almost certainly have failed as well if the government (as the majority shareholder at the time) had not been willing on two occasions to provide a "capital injection." The size of the second (1990) injection was disclosed to be NZ\$620 million. Honohan and Klingebiel estimate that the total fiscal cost of the crisis was 1.0 percent of GDP. Although this cost is comparatively low, in dollar terms it is substantial. The policy lessons revealed by this turbulent episode prompted authorities to redesign the RBNZ's early warning system to emphasize self-reporting by directors.

Australia experienced a crisis of similar magnitude. Although it also did not offer explicit deposit insurance, its winding-up regime gave depositors preference over other 
creditors (a feature enacted in 1959). Authorities made minor changes in the substance of its disclosure, intervention, and detection regimes. Without triggering a whistleblowing obligation, directors of a distressed Australian bank can still stand by while managers search out and exploit loopholes that can conceal losses. Governmental intervention rights continue to depend primarily on examiners' ability to uncover and verify hidden problems. However, the Australian Stock Exchange (ASX) imposes disclosure and whistle-blowing obligations on listed banks. These obligations fall on the banking "entity" rather than specific officeholders and shift the burden of further disclosure onto the $\mathrm{ASX}^{2}$. This leaves the forensic accounting burden that supervisory officials must meet before they can intervene somewhat higher in Australia than in New Zealand and more subjective than in the U.S.

Although the U.S. operates an insolvency-detection regime similar to Australia's, taxpayer losses in the savings-and-loan debacle led Congress to beef up and mechanize regulators' intervention and winding-up rights. Along a specified ladder of positive networth thresholds, U.S. banking law now authorizes an escalating series of interventions and requires regulators to intervene ever more strongly as a bank's accounting net-worth declines. The Federal Deposit Insurance Corporation Improvement Act of 1991 instructs bank regulators to demand that banks take particularly strong corrective actions whenever their book-value net worth falls below 4 percent of assets. If these remedies fail to stop the slide in a bank's accounting net worth, regulators must order a stockholder recapitalization. If the recapitalization does not materialize or proves insufficient, authorities must - after due notice — put the bank into a receivership or conservatorship (in most circumstances) once its book-value net worth falls below 2 percent of assets. Putting stockholders on notice lets them avoid closure by injecting new capital or finding a merger partner. They should exercise one of these options if they believe that $\mathrm{N}_{\mathrm{E}}$ is still positive. The alternatives that these options offer prevent the 2-percent threshold from being characterized under common law as an "unjust taking" of private assets by the government.

\footnotetext{
${ }^{2}$ ASX Listing Rule 3.1 states: "Once an entity is or becomes aware of any information concerning it that any reasonable person would expect to have a material effect on the price or value of an entity's securities, the entity must immediately tell ASX that information."
} 
APRA employs triggers for intervention as well. The process is called PAIRS/SOARS. Experts evaluate the financial health of a bank and its systemic significance. This evaluation feeds into a four-way classification scheme for calibrating the need for regulatory attention and discipline: normal; oversight; mandated improvement; restructuring. Quantitative elements in these assessments influence but do not formally dictate APRA's response.

$\underline{\text { Potential Conflict between the Australian and New Zealand Strategies for Insolvency- }}$ Detection The success of any partnership depends on how much the partners disagree and how well they can handle disagreement. Potential conflict between host-country and home-country supervisors intensifies as a bank weakens. Divergences in disclosure and detection regimes allow home and host regulators to compile and react to evidence of bank weakness in different ways.

Mayes (2005) distinguishes four regimes of market and supervisory response to individual-bank accounting reports. In the first regime, market participants and supervisors are satisfied with the bank's condition and performance and impose no penalties. In the second regime, the bank manages to meet all supervisory tests, but market participants begin to impose risk premiums. In the third case, supervisors begin to be concerned and should be acting to strengthen the bank. In the fourth case, the bank is economically insolvent and authorities need to take over the bank and relicense it.

Within Mayes' third regime, home and host supervisors may not be equally concerned. Even when both sets of regulators enjoy the same acuity of vision, nationalistic norms and reputational concern might tempt home-country officials to delay insolvency resolution (Kane, 1989). Home-country delays give managers of a failing institution an opportunity to shift bad assets to the host jurisdiction. When banking problems surface during a top official's watch, his or her reputation is at risk. In some cases, agency leaders may even be grateful that accounting trickery can temporarily hide evidence of weakness from the market. Similarly, in the host country, effective action may also be delayed by the threat of career and reputational penalties that politically important foreign banks may be able to exert on particular ministers both directly and through the press. 
As the home-country regulator, it is APRA's job to assess the strength of each cross-country conglomerate institution. Although rumors can speed up the process, Australia maintains a traditional zero-value accounting threshold for failing a bank or banking conglomerate. It is easy to imagine circumstances in which information transmitted by resident directors would lead the RBNZ to recognize the insolvency of an Australian bank's New Zealand subsidiary long before periodic reports and APRA's examination-based verification methods could ascertain whether the economic net worth of the Australian parent was truly strong enough to cover New Zealand losses on a consolidated basis.

These are precisely the circumstances in which preserving RBNZ intervention rights would protect New Zealand taxpayers from potential weaknesses or mistakes in Australian supervision. In cases where the conglomerate organization was in fact weak, home-country managers would not want the RBNZ to force APRA to examine their accounts more closely. Given the RBNZ policy of local incorporation, a supervisorily compliant, but economically insolvent Australian parent would recognize the value of making sure that, at each quarterly reporting date, it had shuffled enough good assets to its New Zealand subsidiary to keep local accountants and directors from blowing any whistles. Backed up by local directors' obligation to inform the RBNZ of any transaction than weakens a New Zealand institution, this incentive protects New Zealand taxpayers from being saddled with losses incurred in Australia. However, this protection would unravel either if Australian banks were allowed to operate in New Zealand through branch offices or if the Australian scheme for insolvency detection were simply to displace the New Zealand one.

\section{Summary}

Prudential regulation seeks to assure the safety and soundness of the financial sector. As institutions and markets evolve, so must processes for resolving incentive conflicts in financial transactions.

The inherited regulatory cultures of Australia and New Zealand show differences in the structure of legal authority, in their reliance on position limits and other rules, and 
in the technology used to monitor bank risk-taking and net worth. Lasting differences in regulatory culture evolve experimentally, as tentative solutions to recognized societal problems that prove themselves able to meet the test of time.

The persistence of substantial differences implies that authorities in the two countries have had to respond to fundamental differences in operative political, cultural, and risk-taking environments. Replacing New Zealand's financial regulatory system with that of Australia would simultaneously deny New Zealand citizens the hard-won benefits of this evolutionary process and make it hard for them to hold regulatory officials in Australia accountable politically for costs their policy decisions might impose on the Kiwi economy.

The Mishan welfare criterion tells us that trans-Tasman regulatory arrangements cannot be fairly harmonized unless and until political mechanisms can be established that enable regulators and citizens of both countries to observe and adequately discipline the tradeoffs that responsible officials make between their own and partner-country interests when these interests diverge. Only by crafting the equivalent of a strong and fair prenuptial agreement can efforts to marry the regulation of individual-country banking markets be expected to succeed. At a minimum, each prenuptial agreement must impose bilateral obligations to intervene well in advance of book-value insolvency and to disclose emerging concerns to partner regulators promptly. To back up these obligations, the agreement should authorize partner regulators to sue in a neutral court to recover damages from countries whose officials appear to have violated this right. 
December 2, 2005

\section{REFERENCES}

Aghion, Philippe, Patrick Bolton, and Steven Fries, 1999. “Optimal Design of Bank Bailouts: The Case of Transition Economies," Journal of Institutional and Theoretical Economics, 55(March), 51-70.

Altunbas, Yener, and David Marqués Ibáñez, 2004. "Mergers and Acquisitions and Performance in Europe: The Role of Strategic Similarities," Frankfurt: European Central Bank, Working Paper No. 398 (October).

Bank for International Settlements, Committee on Banking Regulations and Supervisory Practices, 1975. Report to the Governors on the Supervision of Banks' Foreign Establishments (the "Concordat"), Geneva (September 26).

Basel Committee on Banking Supervision, 1997. Core Principles for Effective Banking Supervision, Geneva (September).

(November). , 2001. Core Principles: Cross-Sectional Comparison, Geneva 2003. High-Level Principles for the Cross-Border Implementation of the New Accord, Geneva (August).

Brash, Donald T., 1996. "A New Approach to Bank Supervision," Address to the Center for the Study of Financial Innovation, London (June 5). , 2000. "Central Banks and Financial System Stability in an Uncertain World," Address to the Belgian Financial Forum (June 6).

Honohan, Patrick, and Daniela Klingebiel, 2003. "The Fiscal Cost Implications of an Accommodating Approach to Banking Crises." Journal of Banking and Finance, 27(August), 1539-1560.

Joint Press Conference, 2005. Transcript of Proceedings Featuring Michael Cullen, New Zealand Finance Minister and Peter Costello, Australian Treasurer, Wellington, NZ (Feb. 17).

Kane, Edward J., 1989. "Changing Incentives Facing Financial-Services Regulators," Journal of Financial Services Research 2(September), 265-274.

Ledingham, Peter, 1995. "The Review of Bank Supervision Arrangements in New Zealand: The Main Elements in the Debate," Reserve Bank of New Zealand: Bulletin, 58 (September), 163-171. 
Mishan, E.J., 1969. Welfare Economics: An Assessment, Amsterdam and London: North Holland Publishing Company

Mayes, David G., 2005. "Crisis Resolution of Large Banks in Small Countries," Slideshow Prepared for Norges Bank Conference on Banking Crisis ResolutionTheory and Policy (June).

Mortlock, Geof, 2003. "New Zealand's Financial Sector Regulation," Reserve Bank of New Zealand: Bulletin, 66(December), 5-49.

Schüler, Martin, 2003. "Incentive Problems in Banking Supervision - The European Case,” Mannheim, Germany: ZEW Discussion Paper No. 03-62.

Todd, Walker, 2002. "Central Banking in a Democracy: The Problem of the Lender of Last Resort," in P.A. McCoy (ed.), Financial Modernization after Gramm-LeachBliley, Newark, NJ: Matthew Bender.

Tripe, David, 2001. "Banking Supervision by Disclosure: A Review of the New Zealand Regime," Centre for Banking Studies, Massey University, Palmerston North, NZ (unpublished).

Weston, J. Fred, Juan A. Siu, and Brian A. Johnson, 2001. Takeovers, Restructuring, and Corporate Governance, Third Edition. Upper Saddle River, NJ: Prentice-Hall Inc.

Woolford, Ian, and Adrian Orr, 2005. "The Limits to Hospitality," The Financial Regulator, 10(June), 41-46. 


\section{TABLE 1}

\section{Paths by Which Bad NeWs May Reach Top Regulators}

\begin{tabular}{|c|c|c|c|}
\hline $\begin{array}{c}\text { Ways in Which } \\
\text { Crippling News } \\
\text { Surfaces }\end{array}$ & $\begin{array}{l}\text { Initial Source of } \\
\text { Corrective } \\
\text { Pressure }\end{array}$ & $\begin{array}{c}\text { Ways in Which } \\
\text { Bank Management } \\
\text { Can Challenge or } \\
\text { Stifle Bad News }\end{array}$ & $\begin{array}{l}\text { Ways in Which } \\
\text { Regulators Can } \\
\text { Lessen the Call to } \\
\text { Action Generated } \\
\text { by the Bad News }\end{array}$ \\
\hline $\begin{array}{l}\text { 1. Government- } \\
\text { Initiated Path }\end{array}$ & $\begin{array}{l}\text { Government } \\
\text { examiners discover } \\
\text { irregularities in loan } \\
\text { underwriting, } \\
\text { documentation, or } \\
\text { loss reserves during } \\
\text { an ordinary bank } \\
\text { examination }\end{array}$ & $\begin{array}{l}\text { Exercise rights to } \\
\text { appeal examiner } \\
\text { writedowns }\end{array}$ & $\begin{array}{l}\text { Higher-ups may } \\
\text { modify examiner's } \\
\text { "pencil report" }\end{array}$ \\
\hline $\begin{array}{l}\text { 2. Bank-Initiated } \\
\text { Paths }\end{array}$ & $\begin{array}{l}\text { A conscientious } \\
\text { internal } \\
\text { whistleblower } \\
\text { provides evidence to } \\
\text { either: } \\
\text { a. the bank's } \\
\text { external auditor } \\
\text { b. the bank's board } \\
\text { of directors } \\
\text { c. regulatory } \\
\text { staffmembers. }\end{array}$ & $\begin{array}{l}\text { a. Auditors may be } \\
\text { persuaded to } \\
\text { ignore or } \\
\text { marginalize the } \\
\text { evidence } \\
\text { b. Boardmembers } \\
\text { may be persuaded } \\
\text { to ignore the } \\
\text { evidence } \\
\text { c. Managers may } \\
\text { succeed in } \\
\text { demonizing the } \\
\text { whistleblower }\end{array}$ & $\begin{array}{ll}\text { a. } & \text { Not applicable } \\
\text { b. Not applicable } \\
\text { c. Regulators may } \\
\text { treat the } \\
\text { whistleblower as } \\
\text { a mean-spirited } \\
\text { troublemaker }\end{array}$ \\
\hline $\begin{array}{l}\text { 3. Auditor-Initiated } \\
\text { Path }\end{array}$ & $\begin{array}{l}\text { Auditor finds } \\
\text { irregularities and } \\
\text { either quits, is fired, } \\
\text { or issues a qualified } \\
\text { report }\end{array}$ & $\begin{array}{l}\text { Managers concoct a } \\
\text { persuasive cover } \\
\text { story for the } \\
\text { impasse. }\end{array}$ & $\begin{array}{l}\text { Regulators may } \\
\text { ignore the audit } \\
\text { impasse }\end{array}$ \\
\hline $\begin{array}{l}\text { 4. Creditor-Driven } \\
\text { Path }\end{array}$ & $\begin{array}{l}\text { News about auditor } \\
\text { issues, leaks, or } \\
\text { autonomous rumors } \\
\text { undermine depositor } \\
\text { confidence or the } \\
\text { confidence of } \\
\text { suppliers of } \\
\text { interbank loans }\end{array}$ & $\begin{array}{l}\text { Managers may } \\
\text { collateralize and/or } \\
\text { pay very high } \\
\text { interest on large } \\
\text { deposits or } \\
\text { interbank loans }\end{array}$ & $\begin{array}{l}\text { Central bank may } \\
\text { replace private } \\
\text { funding with } \\
\text { discount-window } \\
\text { loans }\end{array}$ \\
\hline
\end{tabular}

